\title{
Measurement of anionic sites of rat epididymal spermatozoa using tritiated polycationized ferritin
}

\author{
P. Toowicharanont and M. Chulavatnatol \\ Department of Biochemistry, Faculty of Science, Mahidol University, Rama VI Road, \\ Bangkok 10400, Thailand
}

\begin{abstract}
Summary. Anionic sites of rat epididymal spermatozoa were measured at $\mathrm{pH} 7 \cdot 4$ using tritiated polycationized ferritin. The spermatozoa from the caput region had $1.25 \pm 0.06 \times 10^{6}$ anionic sites per cell and a binding constant of $1.26 \pm 0.01 \times$ $10^{6} \mathrm{M}^{-1}$. Spermatozoa from the cauda region had $1.50 \pm 0.09 \times 10^{6}$ anionic sites per cell and a binding constant of $4.84 \pm 0.82 \times 10^{6} \mathrm{M}^{-1}$. The values were mean $\pm \mathrm{s}$.d. The anionic sites were partly sensitive to treatments with neuraminidase, trypsin and Triton X-100.
\end{abstract}

\section{Introduction}

Increase in the net negative charges on the sperm surface during epididymal transit has been demonstrated by electrophoresis (for review, see Bedford \& Cooper, 1978) and by an isoelectrofocussing technique (Moore, 1979; Hammerstedt, Keith, Hay, Deluca \& Amann, 1979). Since the increase could be due to an increase in the negative charge residues or to a decrease in the positive charge residues on the sperm surface, it is necessary to quantitate each type of charged residue separately.

The binding of colloidal iron hydroxide has been used to demonstrate the increase in the negative charges on maturing spermatozoa (Bedford \& Cooper, 1978; Holt, 1980). However, the acidic $\mathrm{pH}$ required for binding colloidal iron hydroxide is non-physiological and likely to alter the negatively charged residues to various degrees, depending on their $\mathrm{pKa}$ values (Hughes, 1976). It is therefore unsatisfactory to relate such binding data to the negative charges on the sperm surface at physiological $\mathrm{pH}$. The negative charges or anionic sites on cell surfaces at neutral $\mathrm{pH}$ can now be measured by techniques involving cationized ferritin (Lin-Liu \& Bondareff, 1981) and tritiated polycationized ferritin (Grinnell \& Hays, 1979). We have used the latter method to re-examine the increase in the sperm surface negative charges during epididymal transit.

\section{Materials and Methods}

Spermatozoa were extruded from adult albino rats into phosphate-buffered saline (PBS) containing $0.15 \mathrm{M}-\mathrm{NaCl}$ in $5 \mathrm{~mm}$-phosphate, $\mathrm{pH} 7.4$ at $4^{\circ} \mathrm{C}$ as previously described (Chulavatnatol, Hasibuan, Yindepit \& Eksittikul, 1977). The cells were washed 5 times by centrifugation at $600 \mathrm{~g}$ for $15 \mathrm{~min}$ at $4^{\circ} \mathrm{C}$ and finally resuspended in ice-cold PBS. The cell suspension was then inspected under a phasecontrast microscope and found to be free of contaminating debris. The spermatozoa were counted in a haemocytometer after washing.

Tritiated polycationized ferritin $\left(\left[{ }^{3} \mathrm{H}\right] \mathrm{PCF}\right)$ was prepared according to the method of Grinnell 
\& Hays (1979). A mixture $(1 \mathrm{ml})$ of $30 \mathrm{mg}$ ferritin, $30 \mu \mathrm{Ci}$ 2,3-[N- $\left.{ }^{3} \mathrm{H}\right]$ putrescine- $\mathrm{HCl}$ (sp. act. $25.4 \mathrm{Ci} / \mathrm{mmol}$; New England Nuclear, Boston, Massachusetts, U.S.A.) and $80 \mathrm{mg}$ 1-ethyl-3-(3dimethyl)-carbodiimide- $\mathrm{HCl}$ (EDC; Pierce Chemical, Rockford, Illinois, U.S.A.) was adjusted to pH 6.5 with $\mathrm{HCl}$ and incubated at room temperature $\left(27^{\circ} \mathrm{C}\right)$ with gentle constant shaking. After $30 \mathrm{~min}$, a solution $(4 \mathrm{ml})$ containing $2 \mathrm{M}$-putrescine- $\mathrm{HCl}$ (Sigma, St Louis, Missouri, U.S.A.) and $320 \mathrm{mg}$ EDC was added. The incubation was allowed to continue for another $2 \mathrm{~h}$, during which the $\mathrm{pH}$ of the solution was maintained at 6.5 by periodic additions of $\mathrm{HCl}$. Then the solution was left at room temperature overnight. Excess putrescine was removed by exhaustive dialysis at $4^{\circ} \mathrm{C}$ for $24 \mathrm{~h}$ against 3 changes of 4 litres $0.15 \mathrm{M}-\mathrm{NaCl}$. The $\left[{ }^{3} \mathrm{H}\right] \mathrm{PCF}$ was stored at $4^{\circ} \mathrm{C}$ until use. The protein concentration in the $\left[{ }^{3} \mathrm{H}\right] \mathrm{PCF}$ preparation was determined by its absorbance at $279 \mathrm{~nm}$ and calculated using an extinction coefficient value of a $1 \%$ solution at $279 \mathrm{~nm}$ of 79.9 . From three preparations, the average specific radioactivity was 194 c.p.m./ $/$ g protein or $9.1 \times 10^{13}$ c.p.m./ mol $\left[{ }^{3} \mathrm{H}\right] \mathrm{PCF}$, based on the $\mathrm{M}_{\mathrm{r}}$ of PCF being 467000 .

Binding of $\left[{ }^{3} \mathrm{H}\right] \mathrm{PCF}(100 \mu \mathrm{g})$ with washed spermatozoa $\left(1.2 \times 10^{7}\right)$ in PBS was performed in a total volume of $250 \mu \mathrm{l}$ at room temperature for $10 \mathrm{~min}$. At the end of the incubation, the spermatozoa were centrifuged through $1 \mathrm{ml}$ of $10 \%$ Ficoll-PBS in a Pasteur pipette with sealed tip at $600 \mathrm{~g}$ for $10 \mathrm{~min}$ at room temperature. The packed spermatozoa were collected by breaking the tip of the pipette into $10 \mathrm{ml}$ of $25 \%$ Triton X-114/xylene scintillation fluid and the bound radioactivity was determined using a Packard liquid scintillation counter.

Treatments of the spermatozoa by protease-free neuraminidase (Vibrio cholera, $0 \cdot 1 \mathrm{unit} / \mathrm{ml})$, by trypsin $(0.3 \mathrm{mg} / \mathrm{ml})$ or by Triton X-100 $(1 \%, \mathrm{v} / \mathrm{v})$ containing $2 \mathrm{mM}$-dithiothreitol before the binding with $\left[{ }^{3} \mathrm{H}\right] \mathrm{PCF}$ were performed as described previously (Toowicharanont \& Chulavatnatol, 1983).

\section{Results}

\section{Binding conditions}

To measure the anionic sites of the spermatozoa correctly, the incubation time, sperm concentration, amount of $\left[{ }^{3} \mathrm{H}\right] \mathrm{PCF}$ added and intactness of the spermatozoa were considered. Using $100 \mu \mathrm{g}\left[{ }^{3} \mathrm{H}\right] \mathrm{PCF}$ and the PBS-washed spermatozoa from the cauda epididymidis $\left(1.2 \times 10^{7}\right.$ cells), binding was rapid, reaching half equilibrium in $0.5 \mathrm{~min}$ and full equilibrium within $10 \mathrm{~min}$ (data not shown). Using $100 \mu \mathrm{g}$ [ $\left.{ }^{3} \mathrm{H}\right] \mathrm{PCF}$ and an incubation time of $10 \mathrm{~min}$, the binding increased linearly with increasing amount of spermatozoa used up to $1.5 \times 10^{7}$ cells (Text-fig. 1). The amount

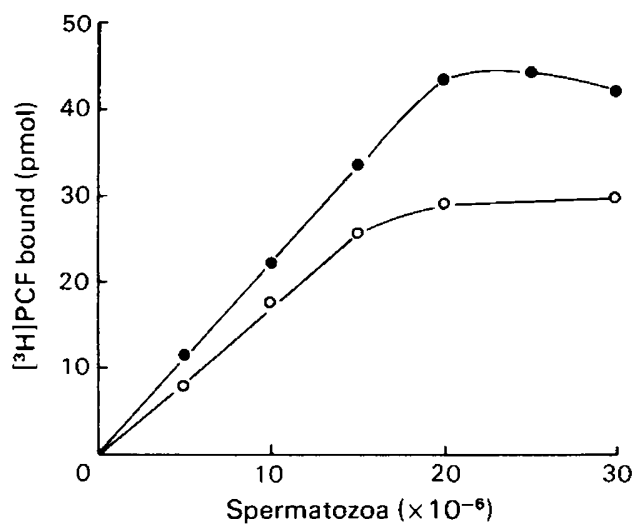

Text-fig. 1. Binding of $\left[{ }^{3} \mathrm{H}\right] \mathrm{PCF}$ to various amounts of rat spermatozoa from the caput $(O)$ and cauda (O) epididymidis. The spermatozoa were washed in PBS and incubated at room temperature with $100 \mu \mathrm{g}\left[{ }^{3} \mathrm{H}\right] \mathrm{PCF}$ for $10 \mathrm{~min}$ in $\mathrm{PBS}$. Each point was an average of 2 determinations. 
of added $\left[{ }^{3} \mathrm{H}\right] \mathrm{PCF}$ required to saturate the binding sites of $1.2 \times 10^{7}$ spermatozoa in 10 min was found to be between 80 and $100 \mu \mathrm{g}$ (Text-fig. 2). The intactness of the spermatozoa was suggested by the observation that the binding curves of the PBS-washed spermatozoa (Text-fig. 2) were identical to those of cells washed by centrifugation through Ficoll (Harrison, 1976) or sucrose (Jones, Pholpramool, Setchell \& Brown, 1981) (data not shown). These results led to the binding technique for the PBS-washed spermatozoa as described in 'Materials and Methods'.

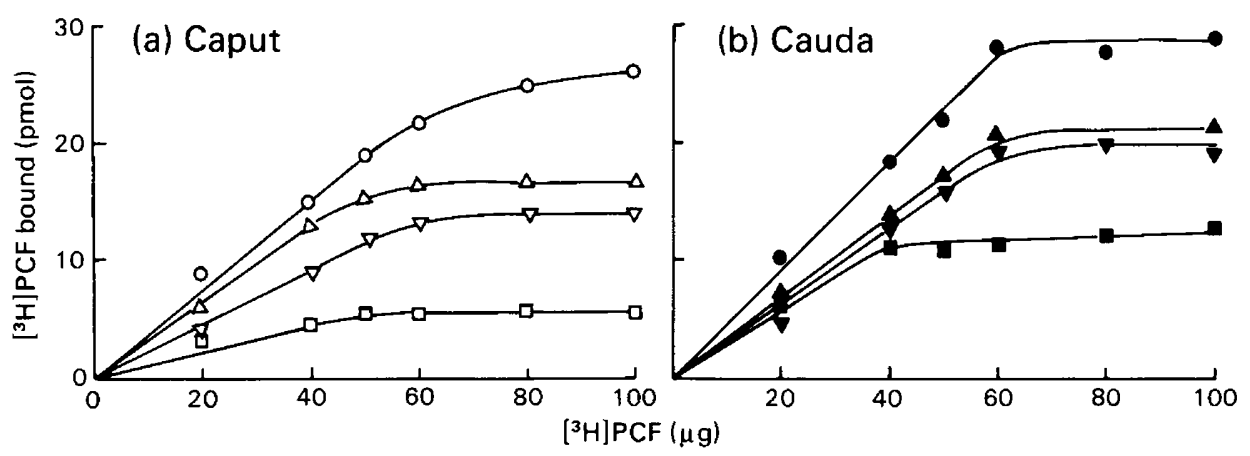

Text-fig. 2. Binding of $\left[{ }^{3} \mathrm{H}\right] \mathrm{PCF}$ to rat spermatozoa from the caput and cauda epididymidis. Before binding, PBS-washed spermatozoa $(O, O)$ were treated with neuraminidase $(\triangle, \Delta)$, trypsin $(\nabla, \nabla)$ or Triton X-100 $(\square, \square)$. After treatment, the spermatozoa were washed twice in PBS and then $1.2 \times 10^{7}$ spermatozoa were incubated with various amounts of $\left[{ }^{3} \mathrm{H}\right] \mathrm{PCF}$ in PBS at room temperature for $10 \mathrm{~min}$. Each point was an average of 2 determinations.

\section{Anionic sites}

The amount of $\left[{ }^{3} \mathrm{H}\right] \mathrm{PCF}$ bound to spermatozoa from the caput epididymidis was significantly less than that bound to the spermatozoa from the cauda (Table 1). During sperm maturation, the calculated number of anionic sites per cell increased by $20 \%$ but there was a decrease in the binding constant estimated according to the method of Grinnell \& Hays (1979).

Table 1. Binding of tritiated polycationized ferritin $\left(\left[{ }^{3} \mathrm{H}\right] \mathrm{PCF}\right)$ to rat epididymal spermatozoa

\begin{tabular}{|c|c|c|c|}
\hline $\begin{array}{l}\text { Epididymal } \\
\text { region }\end{array}$ & $\begin{array}{l}{\left[{ }^{3} \mathrm{H}\right] \mathrm{PCF} \text { bound }} \\
\left(\mathrm{pmol} / 10^{6} \text { cells) }\right.\end{array}$ & $\begin{array}{c}\text { Anionic sites } \\
\text { per cell }\left(\times 10^{-6}\right)\end{array}$ & $\begin{array}{l}\text { Binding constant } \\
\left(\mathrm{M}^{-1}\right)\left(\times 10^{-6}\right)\end{array}$ \\
\hline $\begin{array}{l}\text { Caput } \\
\text { Cauda }\end{array}$ & $\begin{array}{r}2.08 \pm 0.10(6) \\
* 2.49 \pm 0.16(6)\end{array}$ & $\begin{array}{r}1.25 \pm 0.06(6) \\
* 1.50 \pm 0.09(6)\end{array}$ & $\begin{array}{r}1.26 \pm 0.01(3) \\
* * 4.84 \pm 0.82(3)\end{array}$ \\
\hline
\end{tabular}

Values are mean \pm s.d. for the no. of observations in parentheses.

Values significantly different from caput values: ${ }^{*} P<0.05,{ }^{* *} P<0.025$.

\section{Effects of enzymes and detergent}

Since treatment with neuraminidase, trypsin or Triton X-100 decreases sperm-bound sialic acids (Toowicharanont \& Chulavatnatol, 1983), the sensitivity of the anionic sites on the sperm surface to these treatments was examined (Text-fig. 2). The anionic sites were partly sensitive to pre-treatment by these agents with the following order of sensitivity: Triton $X-100>$ trypsin $>$ neuraminidase. Furthermore, the anionic sites of spermatozoa from the cauda were less sensitive to each treatment than those of spermatozoa from the caput epididymidis. 


\section{Discussion}

Polycationized ferritin has long been used to study the ultrastructural topography of cell surface anionic sites (Danon, Goldstein, Marikovsky \& Skutelsky, 1972). Since a $\left[{ }^{3} \mathrm{H}\right] \mathrm{PCF}$ molecule is large and contains numerous positively charged amino groups from putrescine, an anionic site on the sperm surface that is capable of binding it should be a domain of the surface which consists predominantly of negatively charged residues. Therefore, an increase in anionic sites during sperm maturation (Table 1) is interpreted as an increase in negative charge residues, confirming findings with other techniques (Bedford \& Cooper, 1978; Hammerstedt et al., 1979; Moore, 1979; Holt, 1980).

For the rat epididymal spermatozoa, the binding was not proportional to the sperm number when a large number $\left(>2 \times 10^{7}\right)$ of spermatozoa was used, suggesting a possible crowding effect. Too much $\left[{ }^{3} \mathrm{H}\right] \mathrm{PCF}$ is also undesirable since free ferritin, which may be a contaminant of the $\left[{ }^{3} \mathrm{H}\right] \mathrm{PCF}$ preparation, can bind at a level of $\geqslant 1 \mathrm{mg} / \mathrm{ml}$ to rabbit spermatozoa (Schrader, Eng \& Metz, 1981), and can probably compete for the anionic sites. Such interference is not expected in this study because the total $\left[{ }^{3} \mathrm{H}\right] \mathrm{PCF}$ used was $0.4 \mathrm{mg} / \mathrm{ml}$ and contaminating free ferritin, if present, would be much less.

The fact that sperm anionic sites increase (Table 1) while the sperm-bound sialic acids decrease (Toowicharanont \& Chulavatnatol, 1983) during sperm maturation suggests that the decrease in sperm sialic acids must be accompanied by a greater increase of other negatively charged groups as spermatozoa mature. Such a change may modify the binding strength of the anionic sites and is reflected by a change in the binding constant (Table 1).

P.T. was supported by a WHO-scholarship. We thank Thitika Vajrodaya and Urai Sajjaharutai for skilful secretarial assistance.

\section{References}

Bedford, J.M. \& Cooper, G.W. (1978) Membrane fusion events in the fertilization of vertebrate eggs. In Membrane Fusion, pp. 65-125. Eds G. Poste \& G. L. Nicolson. Elsevier/North-Holland Biomedical Press, Amsterdam.

Chulavatnatol, M., Hasibuan, I., Yindepit, S. \& Eksittikul, T. (1977) Lack of effect of $\alpha$-chlorohydrin on the ATP content of rat, mouse and human spermatozoa. J. Reprod. Fert. 50, 137-139.

Danon, D.L., Goldstein, L., Marikovsky, K. \& Skutelsky, E. (1972) Use of cationized ferritin as a label of negative charges on cell surfaces. $J$, ultrastruct. Res. 38, 500-510.

Grinnell, F. \& Hays, D.C. (1979) Measurement of anionic sites on the surfaces of baby hamster kidney cells using radiolabelled polycationic ferritin. Analyt. Biochem. 97, 400-402.

Hammerstedt, R.H., Keith, A.D., Hay, S., Deluca, N. \& Amann, R.P. (1979) Changes in ram sperm membranes during epididymal transit. Archs Biochem. Biophys. 196, 7-12.

Harrison, R.A.P. (1976) A highly efficient method for washing mammalian spermatozoa. J. Reprod. Fert. 48, 347-353.
Holt, W.V. (1980) Surface-bound sialic acid on ram and bull spermatozoa: deposition during epididymal transit and stability during washing. Biol. Reprod. 23, $847-857$.

Hughes, R.C. (1976) Membrane Glycoproteins : a Review of Structure and Function, p. 12. Butterworths, London.

Jones, R., Pholpramool, C., Setchell, B.P. \& Brown, C.R. (1981) Labelling of membrane glycoproteins on rat spermatozoa collected from different regions of the epididymis. Biochem. J. 200, 457-460.

Lin-Liu, S. \& Bondareff, W. (1981) Chemical determination of cationized ferritin bound to synaptosomes. Expl Cell Res. 133, 480-485.

Moore, H.D.M. (1979) The net surface charge of mammalian spermatozoa as determined by isoelectric focusing. Changes following sperm maturation, ejaculation, incubation in the female tract, and after enzyme treatment. Int. J. Androl. 2, 449-462.

Schrader, S.M., Eng, L.A. \& Metz, C.B. (1981) Immoferritin labeling of rabbit spermatozoa. Gamete Res. 4, 379-386.

Toowicharanont, P. \& Chulavatnatol, M. (1983) Direct assay of bound sialic acids on rat spermatozoa from caput and cauda epididymidis. J. Reprod. Fert. 67, $275-280$. 